\title{
The Assessment of Multimedia Technology in the Teaching of Mathematics in Secondary Schools in Abuja-Nigeria
}

\author{
Blessing Dominic-Ugwu \\ Department of Computer Science, Nigerian Defence Academy (NDA), Kaduna, Nigeria \\ Email: dominic.blessing@yahoo.co.uk \\ Ogwueleka Francisca Nonyelum \\ Department of Computer Science, Nigerian Defence Academy (NDA), Kaduna, Nigeria \\ Email: ogwuelekafn@gmail.com
}

Received: 29 January 2019; Accepted: 14 April 2019; Published: 08 June 2019

\begin{abstract}
Most students especially at the secondary school level have little or no interest in the subject 'Mathematics'. Mathematics teachers have sought for better ways to present the subject so as to captivate the interest of students in order to improve their performance in Mathematics. In this paper, the study on the assessment of multimedia technology method of teaching Mathematics in secondary schools was carried out in Abuja using a public and private secondary school at different locations. The students were taught using the multimedia technology method and the traditional chalk and talk method. The students taught with the multimedia method were termed the experimental group while the students taught with traditional method were termed the control group. Questionnaires were being distributed to the students to fill after which a post-test of the same questions was administered to the students. The responses from the questionnaire were analyzed using frequencies and percentages to find out the method of teaching the students preferred most. Also, the analysis of the post-test result with a paired sample t-test clearly showed there was a significant difference in the mean scores of both teaching methods. The multimedia technology teaching method impacted greatly on the interest and performance of the students in Mathematics.
\end{abstract}

Index Terms-Assessment, multimedia technology, traditional teaching methods, mathematics, students

\section{INTRODUCTION}

"Ref. [1]" Explained educational technology as the methods and professional ways that instigate learning processes and improvement in the performance of teaching by the creation, management and application of the right technological processes and resources. Simply, educational technology is clearly defined as a variety of tools that will appear helpful in learning processes that are problem based or student centered learning which urges the teacher to become a facilitator that will help the learners to discover knowledge rather than to be an instructor who believes that he has all the knowledge to give to the learners who will benefit from it [2]. Educational Technology also known as "Learning Technology" mostly comprised of the use of technological terms and methods in the learning and teaching process [2]. Here the term "Technology" does not only constitute of using recent methods and equipment's like whiteboards, laptops, internet, Wi-Fi, smart phones, YouTube and a variety of others, although today's learners mostly prefer them for their learning potentials, but they also encircle well organized and improved learning management systems, category of information given out, teaching effectively and managing masses of students, feedback mechanisms and methodologies of evaluating performance [3].

Multimedia Learning Environment (MLE) has provided a technological based learning environment where students can provide solutions to problems by exploring things on their own, collaborations and active participation. Models, materials for study and simulations that are media rich such as animated and still graphics, audios and videos implemented in a well-organized pattern promotes learning of new ideologies very effectively. Multimedia interactive nature has provided the enablement to improve on the traditional "chalk-andtalk" method of teaching [4]. Learning has been made more flexible for learners to get use to self-learning strategies. It has enabled both the learners and educators to collaborate in local settings and has greatly expanded both the learners and educators role. It has further encouraged and enhanced peer learning as well as creativity and innovations by individuals [4].

"Ref. [3]" Explained that multimedia enhances the mastering of vital skills of a student by proper practice and drilling. It has also helped in providing solutions to problems by the use of learning how to do it yourself and the understanding of abstract concepts. 
Multimedia has provided improved access to both teachers and students in locations that are remote, facilitated individual and group learning, helped in the managing and administering of classroom activities and the content of learning and also in the simulation of real life problems in different environments. Multimedia Technology has been used and experimented by different institutions of learning at all levels around the world in the modes of their own designs [3].

Continuous developments and changes in all fields of information technology have created new opportunities and channels to boost on educational and teaching methods. On one side, these have boost the abilities of educational instructors to table information in a media enhanced and interactive format in comparison to the chalk and talk traditional method of teaching. It has helped students by giving to them information in ways that has made it easier to comprehend, deal with and retrieve [5].

Multimedia technology method of teaching in mathematics could be adopted as a teaching tool, not as a preconception. Learning mathematics is to mold students' logical reasoning ability of learning. Teaching process must be knowledgeable with the skills, means and methods. In many countries of the world, Mathematics is made a compulsory subject at the primary and secondary level of education due to its importance in the aspect of science and technology [6]. Multimedia courseware mainly uses sounds, images and so on to assist students in understanding and overcoming their difficulties of learning the subject. The application of multimedia technology method to create teaching situations, already existing cognitive structure and new knowledge in students, helps students to be conversant with expanding their knowledge [7].

"Ref. [8]" stated that students' academic achievement in Nigeria has been a great source of concern to government, educators, researchers and parents. [8] Stated that mathematics has a great importance on the national development of Nigeria as a country and such, cannot be overlooked. Most students especially at the secondary school level have little or no interest in the subject 'mathematics'. Mathematics teachers have sought for better ways that the subject can be presented so as to captivate the interest of students in order to improve their performance in mathematics especially at their national examinations. Most of the schools that have adopted the use of multimedia technology as a method of teaching have notice that students tend to perform better and show more interest in class while lessons are going on. This study focuses on the assessment of multimedia technology method of teaching mathematics in secondary school to find out if there is any significant difference between the multimedia method of teaching and the traditional chalk and talk method of teaching and to also find out which of the two methods the students preferred the most.

This study is aimed at assessing the impact multimedia technology method of teaching has made on the improvement and interest of secondary school students in
Mathematics. The study sets to achieve the following objectives:

- To find out the significant difference between multimedia technology method of teaching and the chalk and talk traditional method of teaching on the performance of the students in Mathematics.

- To find out the method of teaching the students preferred most in their Mathematics class.

\section{A. Research Hypothesis}

The research hypothesis for this study was tested at 0.05 level of significant.

- HO1: No significant difference exists between the mean scores of the experimental and control groups.

The structure of the remaining parts of this paper is stated as follows: the review of related work on the assessment of multimedia technology in the teaching of mathematics in secondary schools is been discussed in section two. Section three presents the analysis of data collected and the results from the analysis, section four presents the discussion of the results from the analysis carried out. Finally, section five presents the conclusion and suggestion for further work.

\section{RELATED WORK}

In the research to investigate the effectiveness of multimedia on the performance of students in mathematics in senior secondary schools, [9] selected two schools randomly which was used for the experimental and control group respectively. A Mathematical Achievement Test (MAT) was conducted with a reliability test of 0.81 using KR-20. The test scores were analyzed using ANCOVA. The result from the analysis showed that the mean achievement scores of the experimental group were higher than the mean achievement scores of the control group and consequently, the mean achievement scores for the male students was higher than that of their female counterparts. In conclusion, the use of multimedia in teaching mathematics in secondary schools showed a positive influence on the academic performance of the secondary school students.

In a study to examine the issues that are related to new methods of integrating technology into mathematics education, [10] presented methods of teaching courses in mathematics using multimedia technology. Multimedia based approach was specifically used in the teaching process of calculus and Numerical methods to module the impact on students' performance. Empirical data were collected from the control and experimental group that was created and analyzed. The results from the study showed that the multimedia based teaching and learning process greatly influenced the students' performance positively in the Calculus and Numerical module method. 
In a study to examine the factors that affected teachers' performance and continuous use of a multimediaenhanced content that was developed by using an extension of the Unified Theory of Acceptance and Use of Technology (UTAUT2) as a framework for their research. [11] Gave out 2000 samples to the teachers, out of which 1137 were collected and tested using the regression analysis. From the result gathered with an exception of performance expectancy, every other factor depicted a statistically significant effect on teachers' acceptance and used of the developed content. The findings from the analysis are intended to be adopted by the government and other stake holders to promote the acceptance and the application of the developed framework in schools in Tanzania.

In their paper, [12] developed a software that is user friendly for educational purpose using multimedia technology by developing an animation for three dimensional (3D) model to simulate the assembling and disassembling procedure of high speed flow shock tunnel. The results indicated an increased in the acceptance level of the students' teaching with multimedia approach than the traditional teaching methods in the topic "shock tunnel" in mechanical engineering. With the model, there was an improvement in the level of understanding, interactivity and cognition of the shock wave concept in the shock tunnel facility for the students and the students' scores was improved from 31 percent to 69 percent.

In a paper aimed at investigating the impact multimedia technologies has on the effectiveness and the enhancement of teaching children at the early stage in primary schools in Jordanian. [5] Developed a program to test the abilities of the students on whether they understood the skills and basic knowledge in mathematics. Two groups were selected from a local school based on the way their own classes are distributed. The first group was taught the subject in basic mathematics with the application of a developed program while the second groups were taught with the normal traditional method of teaching. The results showed that using an enhanced multimedia teaching methods could be effective in drawing the children's attention at this age most importantly when cartoon characters are been adopted. There was no significant difference in knowledge skills, absorption of information in relation to gender distribution and learning. Their future work is based on conducting a field study on the students to assess the effectiveness of implementing an interactive multimedia system with a bigger experimental groups using different game applications and apply them to various subjects of area of knowledge so as to give a more generalize outcome of result and to study the necessary disadvantages of making use of these educational games on students.

"Ref. [3]" Carried out a study on analyzing the importance of multimedia in different fields of current educational system. From their literature in reference to various approaches by different universities, it was discovered that multimedia had larger potentials to impact multi-modal, life-long educational and flexibility to different learners. The study of the literatures clearly demonstrated the qualifications of multimedia as a wide source of customized learning environments to absorb various behavioural problems such as the building of confidence and stress reduction. It clearly showed that multimedia when used in the right direction can help in the strengthening of visual processing and building the psychomotor development of intended users.

In the survey done by [13] a multimedia learning system using Microsoft Visual Basic 6.0 and Microsoft Office 2003 was developed which could be used for the learning and teaching of mathematics in senior secondary school. The experiment was used to test the hypothesis that multimedia based learning system to enhance the learning and teaching of mathematics. Empirical study was done to know the reasons for the poor students' performance in mathematics and the opinion of education stakeholders on the importance of multimedia learning system were sought for. The results from the respondents were scientifically and interpreted. Ninety one percent of the sample population agreed to the fact that multimedia based learning system enhances learning and was very beneficial to the learning and teaching of mathematics. The research which was evaluated in Enugu state of Nigeria with a random sample of fifty schools showed that a student who failed with like zero percent with the traditional chalk and talk method of teaching was expected to score at least forty percent when multimedia method was used.

In their study, [14] focused on discovering how effective the teaching mathematics was using information and communication Technology (ICT) in comparison to the traditional teaching method at the secondary level in Pakistan. Samples of 120 students studying mathematics in class ix were considered from the public and private schools using the same syllabus with computer lab facilities were used. The students were grouped into experimental and control group. The group labeled the experimental group was tutored with ICT while the control groups were tutored with the traditional method. A test was administered to the students by their teacher after teaching the students with the two methods. The data collected was their scores and was tested by the split-half (odd-even) method. The result showed that ICT was effective in the achievements of the students academically in mathematics from the private school while ICT was least effective for students' academic achievement for the public schools due to the sufficient availability of technological facilities in the private schools and their homes in comparison to the public schools with no sufficient facilities and less interest in the us technology.

"Ref. [15]" In the study carried out, developed a survey instrument which was used to gather needed information to identify students' preference for multimedia-based mathematics instruction compared to the traditional instruction method. High school students studying mathematics were involved in the study. The students were told to complete a presentation survey voluntarily which was used to evaluate their preference 
for a specific method of presentation. The 5-point Likert scale with 17 statements were assessed which presented a four number code for matching the surveys that were collected throughout a term. The analysis of the collected data was statistically analyzed using the frequency counts, means, percentages and standard deviations measurements. The results showed that there was a significant difference in the survey statements that were associated with students that preferred the multimedia presentation method.

"Ref. [16]" based their study from the results of testing a number of multimedia packages that are interactive which was carried out from grade one to four. The packages in the multimedia contents were mostly applied in subjects like mathematics, science, geography and so on. They came to the conclusion that interactive multimedia proved better compared to the traditional teaching methods that depended on the lecturing and classrooms methods that was done using the talk and chalk method.

\section{ReSEARCh MEthodology}

\section{A. Data Analysis Procedure}

In order to embark on the research for the assessment of teaching mathematics using multimedia technology method in secondary schools in Abuja, a questionnaire was developed to enable us collect the needed data to be used for analysis. Students totaling a hundred and fifty (150) were randomly selected from a public and private secondary school were considered as the sample for this study. The questionnaires were been distributed to the students to fill after being taught the same topic in
Mathematics over a period of time using the multimedia technology teaching method and the traditional teaching method. The students were made to understand that filling the questionnaire was a voluntary process and that there was no penalty whatsoever for not filling the questionnaire but that it will be of help in making the study a success. The students were also subjected to write a post-test made up of ten (10) questions from the selected topic in Mathematics that was taught using both teaching methods. The students who were been taught with the multimedia method were considered as the experimental group while the students who were been taught with the traditional teaching method were considered as the control group. The post-test results were scored over twenty (20) with two (2) marks awarded to each correct questions. The collected data on the post-test was analyzed using the paired samples t-test to test the null hypothesis that was stated. To find out the teaching method the students preferred most in their Mathematics class, the results of the questionnaires gathered were analyzed by finding the frequencies in percentage of the responses to each of the question with a pie chart illustrating the most preferred method of teaching by the students.

\section{B. Results}

The results from the tables and the pie charts depicts high frequencies and percentage for the strongly agree and agree responses which clearly showed that the students highly preferred the multimedia method of teaching to the traditional chalk and talk method of teaching.

Table 1. Descriptive statistics showing the frequency and percentage value response of the students for the questionnaire's first question.

\begin{tabular}{|l|l|l|l|l|l|}
\hline \multicolumn{2}{|l|}{ Multimedia method allows for better understanding of any topic been taught in mathematics } \\
\hline \multirow{3}{*}{} & Valid & Frequency & Percent & Valid Percent & Cumulative Percent \\
\cline { 2 - 7 } & Strongly Disagree & 5 & 3.4 & 3.6 & 3.6 \\
\cline { 2 - 7 } & Disagree & 11 & 7.6 & 7.9 & 11.4 \\
\cline { 2 - 7 } & Neutral & 11 & 7.6 & 7.9 & 19.3 \\
\cline { 2 - 7 } & Agree & 64 & 44.1 & 45.7 & 65.0 \\
\cline { 2 - 7 } & Strongly Agree & 49 & 33.8 & 35.0 & 100.0 \\
\cline { 2 - 7 } & Total & 140 & 96.6 & 100.0 & \\
\hline \multicolumn{7}{|l|}{ Total } & Missing System & 5 & 3.4 & & \\
\hline
\end{tabular}

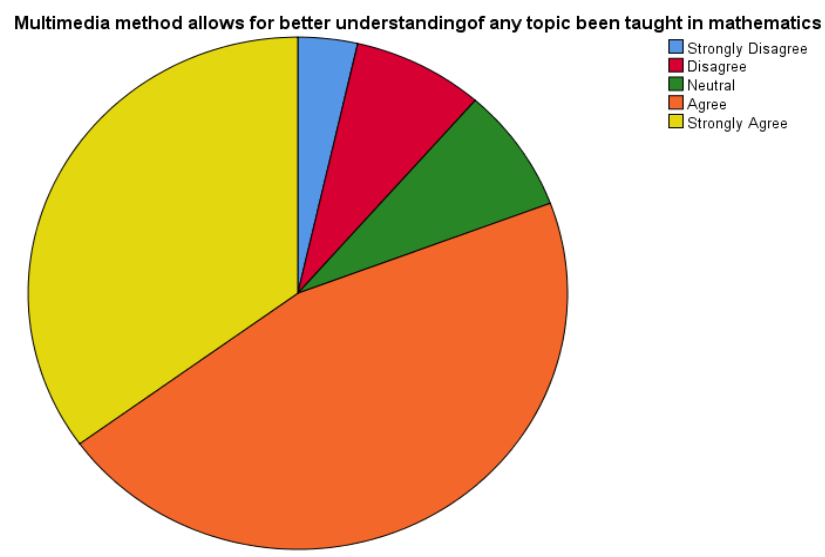

Fig.1. Pie charts for the first question. 
Table 2. Descriptive statistics showing the frequency and percentage value response of the students for the questionnaire's second question.

\begin{tabular}{|c|c|c|c|c|c|}
\hline \multicolumn{6}{|c|}{ Multimedia method helps to improve on the interaction between the teacher and the students } \\
\hline & & Frequency & Percent & Valid Percent & Cumulative Percent \\
\hline \multirow{6}{*}{ Valid } & Disagree & 4 & 2.8 & 2.9 & 2.9 \\
\hline & Neutral & 7 & 4.8 & 5.0 & 7.9 \\
\hline & Agree & 61 & 42.1 & 43.6 & 51.4 \\
\hline & Strongly Agree & 68 & 46.9 & 48.6 & 100.0 \\
\hline & Total & 140 & 96.6 & 100.0 & \\
\hline & Missing System & 5 & 3.4 & & \\
\hline \multicolumn{2}{|r|}{ Minssing system } & 145 & 100.0 & & \\
\hline
\end{tabular}

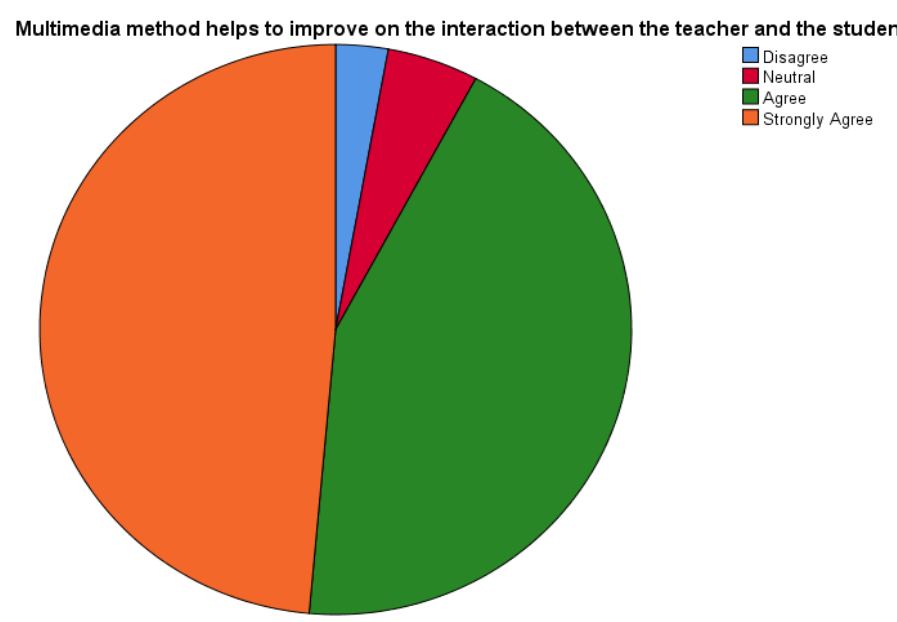

Fig.2. Pie chart for the second question.

Table 3. Descriptive statistics showing the frequency and percentage value response of the students for the questionnaire's third question.

\begin{tabular}{|l|l|l|l|l|l|}
\hline \multicolumn{7}{|l|}{ Multimedia method draws my attention when teaching is on going } \\
\hline \multirow{3}{*}{ Valid } & Disagree & 2 & 1.4 & 1.4 & 1.4 \\
\cline { 2 - 7 } & Neutral & 2 & 1.4 & 1.4 & 2.9 \\
\cline { 2 - 7 } & Agree & 70 & 48.3 & 50.0 & 52.9 \\
\cline { 2 - 7 } & Strongly Agree & 66 & 45.5 & 47.1 & 100.0 \\
\cline { 2 - 7 } & Total & 140 & 96.6 & 100.0 & \\
\hline \multirow{6}{*}{ Total } & $\begin{array}{l}\text { Missing } \\
\text { System }\end{array}$ & 5 & 3.4 & & \\
\hline
\end{tabular}

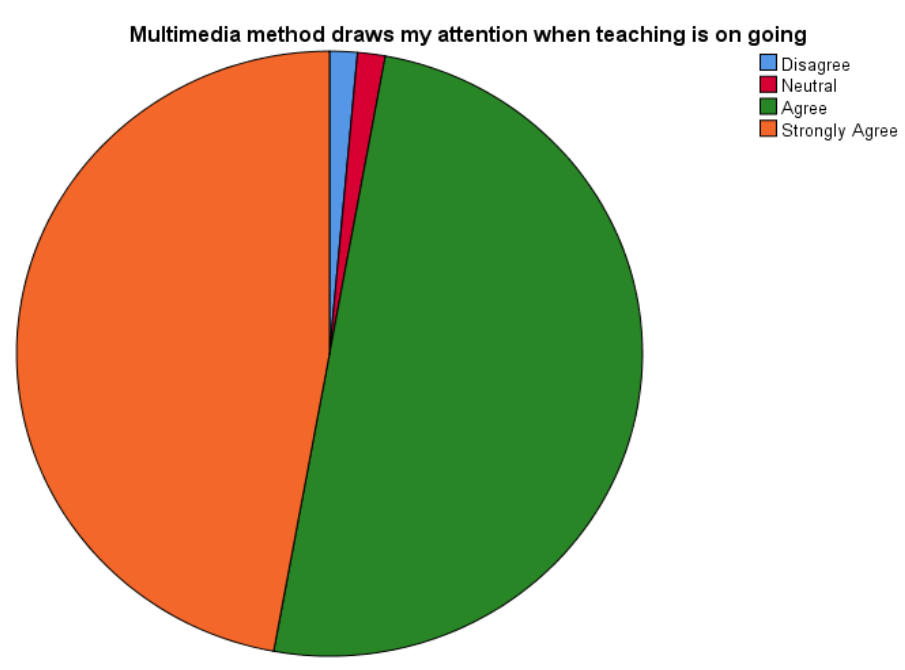

Fig.3. Pie chart for the third question. 
Table 4. Descriptive statistics showing the frequency and percentage value response of the students for the questionnaire's fourth question.

\begin{tabular}{|c|c|c|c|c|c|}
\hline \multicolumn{6}{|c|}{ Multimedia method helps me comprehend better and retain the information gathered } \\
\hline & & Frequency & Percent & Valid Percent & Cumulative Percent \\
\hline \multirow{6}{*}{ Valid } & Disagree & 2 & 1.4 & 1.4 & 1.4 \\
\hline & Neutral & 1 & .7 & .7 & 2.1 \\
\hline & Agree & 76 & 52.4 & 54.3 & 56.4 \\
\hline & Strongly Agree & 61 & 42.1 & 43.6 & 100.0 \\
\hline & Total & 140 & 96.6 & 100.0 & \\
\hline & Missing System & 5 & 3.4 & & \\
\hline \multicolumn{2}{|r|}{ 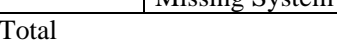 } & 145 & 100.0 & & \\
\hline
\end{tabular}

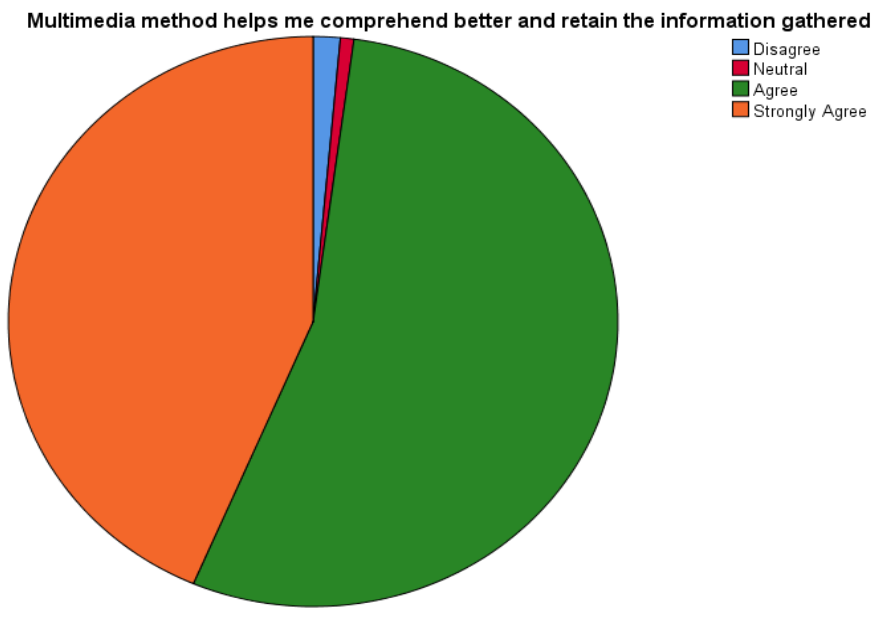

Fig.4. Pie chart for the fourth question.

Table 5. Descriptive statistics showing the frequency and percentage value response of the students for the questionnaire's fifth question.

\begin{tabular}{|l|l|l|l|l|l|}
\hline \multicolumn{6}{|c|}{ Multimedia method helps to increase my knowledge and ability to think fast } \\
\hline \multicolumn{1}{|l|}{} & Frequency & Percent & Valid Percent & Cumulative Percent \\
\cline { 2 - 7 } & Disagree & 4 & 2.8 & 2.9 & 2.9 \\
\cline { 2 - 7 } & Neutral & 4 & 2.8 & 2.9 & 5.7 \\
\cline { 2 - 7 } & Agree & 52 & 35.9 & 37.1 & 42.9 \\
\cline { 2 - 7 } & Strongly Agree & 80 & 55.2 & 57.1 & 100.0 \\
\cline { 2 - 7 } & Total & 140 & 96.6 & 100.0 & \\
\hline & Missing System & 5 & 3.4 & & \\
\hline Total & 145 & 100.0 & & \\
\hline
\end{tabular}

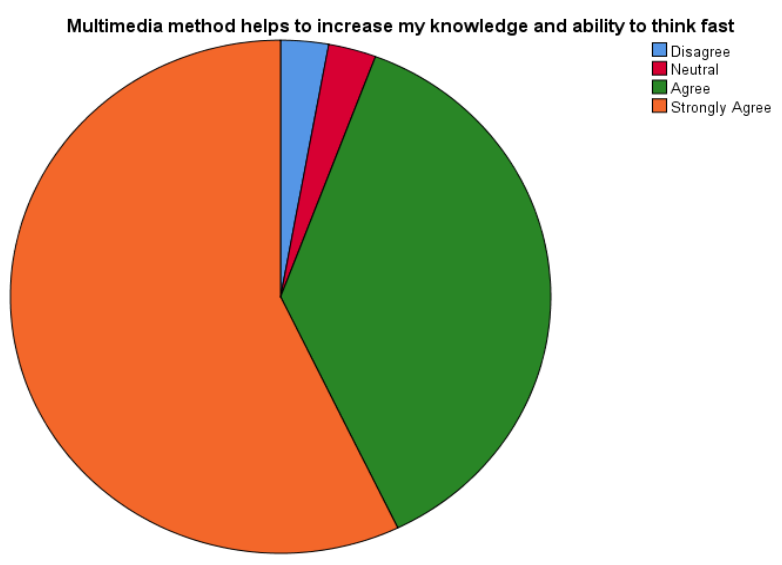

Fig.5. Pie chart for the fifth question. 
Table 6. Descriptive statistics showing the frequency and percentage value response of the students for the questionnaire's sixth question.

\begin{tabular}{|c|c|c|c|c|c|}
\hline \multicolumn{6}{|c|}{ Multimedia method makes notes taking during class much easier } \\
\hline & & Frequency & Percent & Valid Percent & Cumulative Percent \\
\hline \multirow[t]{6}{*}{ Valid } & Disagree & 11 & 7.6 & 7.9 & 7.9 \\
\hline & Neutral & 6 & 4.1 & 4.3 & 12.1 \\
\hline & Agree & 50 & 34.5 & 35.7 & 47.9 \\
\hline & Strongly agree & 73 & 50.3 & 52.1 & 100.0 \\
\hline & Total & 140 & 96.6 & 100.0 & \\
\hline & Missing System & 5 & 3.4 & & \\
\hline \multicolumn{2}{|r|}{ 年 } & 145 & 100.0 & & \\
\hline
\end{tabular}

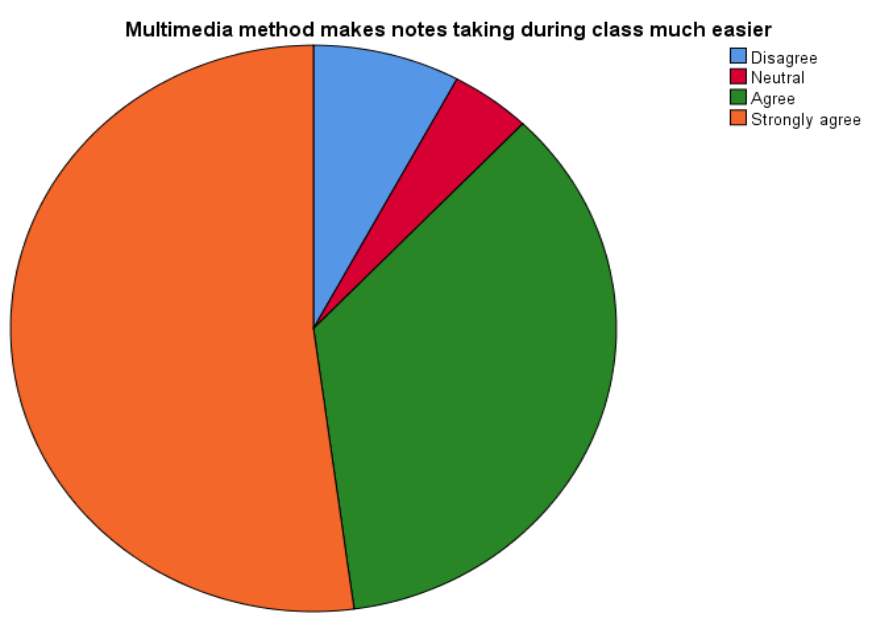

Fig. 6. Pie chart for the sixth question.

Table 7. Descriptive statistics showing the frequency and percentage value response of the students for the questionnaire's seventh question.

\begin{tabular}{|c|c|c|c|c|c|}
\hline \multicolumn{6}{|c|}{ multimedia method makes learning during mathematics class to be more organized } \\
\hline & & Frequency & Percent & Valid Percent & Cumulative Percent \\
\hline \multirow[t]{6}{*}{ Valid } & Disagree & 4 & 2.8 & 2.9 & 2.9 \\
\hline & \begin{tabular}{|l|} 
Neutral \\
\end{tabular} & 2 & 1.4 & 1.4 & 4.3 \\
\hline & Agree & 53 & 36.6 & 37.9 & 42.1 \\
\hline & \begin{tabular}{|l|} 
Strongly Agree \\
\end{tabular} & 81 & 55.9 & 57.9 & 100.0 \\
\hline & Total & 140 & 96.6 & 100.0 & \\
\hline & Missing System & 5 & 3.4 & & \\
\hline \multicolumn{2}{|l|}{ Total } & 145 & 100.0 & & \\
\hline
\end{tabular}

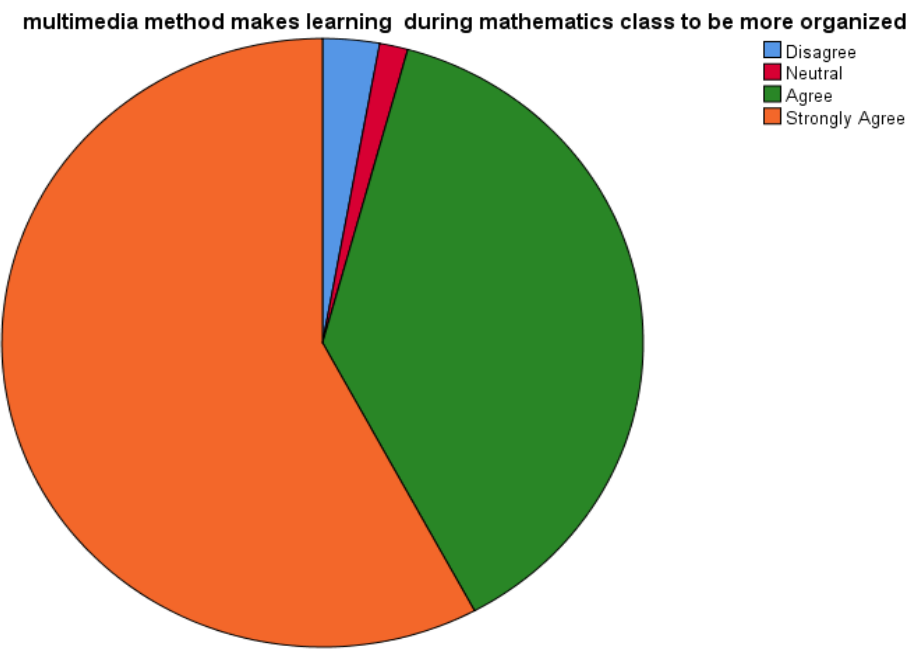

Fig.7. Pie chart for the seventh question. 
Table 8. Descriptive statistics showing the frequency and percentage value response of the students for the questionnaire eighth question.

\begin{tabular}{|c|c|c|c|c|c|}
\hline \multicolumn{6}{|c|}{ Multimedia method gives a better and easier illustrations on any topic in mathematics } \\
\hline & & Frequency & Percent & Valid Percent & Cumulative Percent \\
\hline \multirow[t]{6}{*}{ Valid } & Disagree & 4 & 2.8 & 2.9 & 2.9 \\
\hline & Neutral & 2 & 1.4 & 1.4 & 4.3 \\
\hline & Agree & 59 & 40.7 & 42.1 & 46.4 \\
\hline & Strongly Agree & 75 & 51.7 & 53.6 & 100.0 \\
\hline & Total & 140 & 96.6 & 100.0 & \\
\hline & Missing System & 5 & 3.4 & & \\
\hline \multicolumn{2}{|l|}{ Total } & 145 & 100.0 & & \\
\hline
\end{tabular}

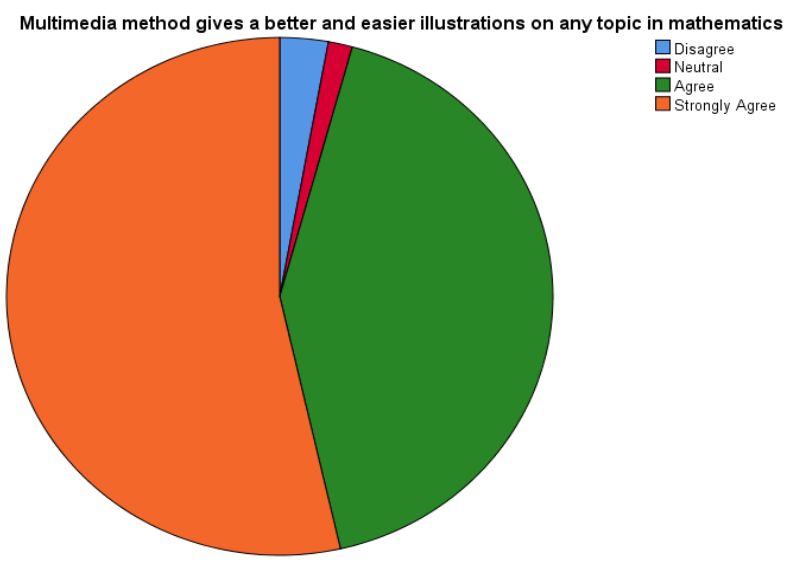

Fig.8. Pie chart for the eighth question.

Table 9. Descriptive statistics showing the frequency and percentage value response of the students for the questionnaire's ninth question.

\begin{tabular}{|c|c|c|c|c|c|}
\hline \multicolumn{6}{|c|}{\begin{tabular}{|l|} 
Multimedia method highlights on vital points \\
\end{tabular}} \\
\hline & & Frequency & Percent & \begin{tabular}{|l} 
Valid Percent \\
\end{tabular} & \begin{tabular}{|l} 
Cumulative Percent \\
\end{tabular} \\
\hline \multirow{6}{*}{ Valid } & Disagree & 7 & 4.8 & 5.0 & 5.0 \\
\hline & Neutral & 1 & .7 & .7 & 5.7 \\
\hline & Agree & 54 & 37.2 & 38.6 & 44.3 \\
\hline & Strongly Agree & 78 & 53.8 & 55.7 & 100.0 \\
\hline & Total & 140 & 96.6 & 100.0 & \\
\hline & Missing System & 5 & 3.4 & & \\
\hline \multicolumn{2}{|l|}{ Total } & 145 & 100.0 & & \\
\hline
\end{tabular}

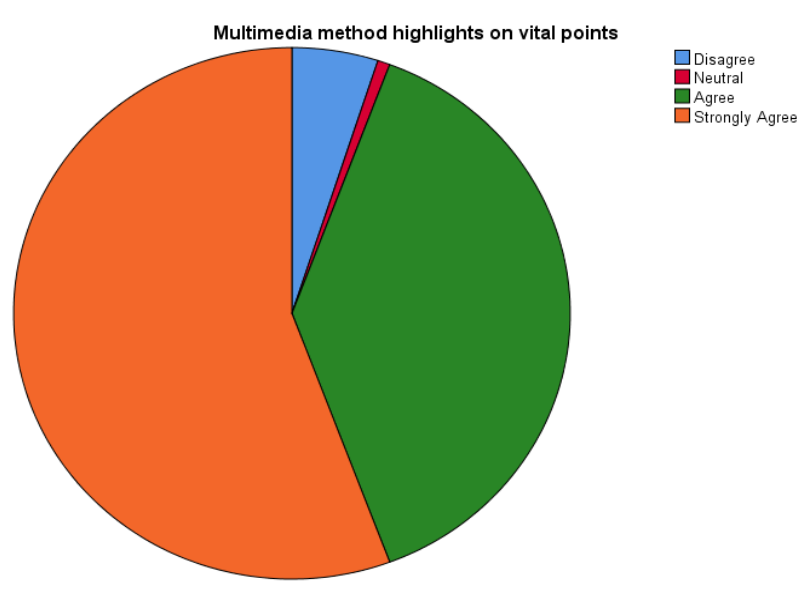

Fig.9. Pie chart for the ninth question. 
Table 10. Descriptive statistics showing the frequency and percentage value response of the students for the questionnaire tenth question.

\begin{tabular}{|c|c|c|c|c|c|}
\hline \multicolumn{6}{|c|}{ I prefer multimedia method of teaching to the traditional method of teaching } \\
\hline & & Frequency & Percent & Valid Percent & Cumulative Percent \\
\hline \multirow[t]{6}{*}{ Valid } & Disagree & 2 & 1.4 & 1.4 & 1.4 \\
\hline & Neutral & 6 & 4.1 & 4.3 & 5.7 \\
\hline & Agree & 53 & 36.6 & 37.9 & 43.6 \\
\hline & Strongly Agree & 79 & 54.5 & 56.4 & 100.0 \\
\hline & Total & 140 & 96.6 & 100.0 & \\
\hline & Missing System & 5 & 3.4 & & \\
\hline \multicolumn{2}{|l|}{ Total } & 145 & 100.0 & & \\
\hline
\end{tabular}

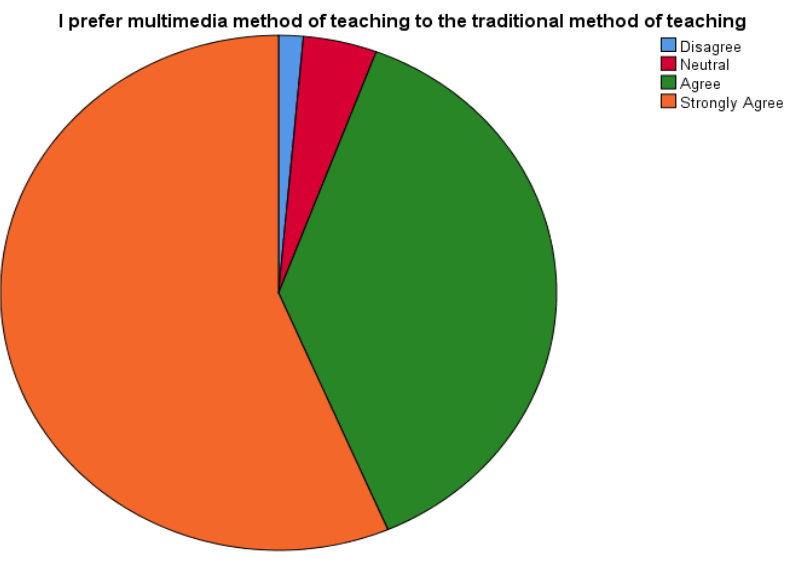

Fig.10. Pie chart for the tenth question.

The result from table 11 clearly depicts the descriptive statistics showing the mean and standard deviation scores for both the experimental group and the control group. The mean score for the experimental group (multimedia method test score) with mean $=3.56$ is larger than the mean score of the control group (traditional method test score) with mean $=1.95$. The standard deviation scores of the both teaching methods shows that the two teaching method are similarly dispersed. $\mathrm{N}$ depicts the number of students that were involved in the analysis.

Table 11. The descriptive statistics showing the mean and standard deviation scores for the multimedia and traditional methods of teaching.

\begin{tabular}{|l|l|l|l|l|l|}
\hline \multicolumn{2}{|l|}{ Paired Samples Statistics } \\
\hline \multicolumn{2}{|l|}{} & Mean & $\mathrm{N}$ & Std. Deviation & Std. Error Mean \\
\hline Pair 1 & $\begin{array}{l}\text { Multimedia Method Test } \\
\text { Score }\end{array}$ & 3.56 & 140 & .578 & .049 \\
\cline { 2 - 6 } & $\begin{array}{l}\text { Traditional Method Test } \\
\text { Score }\end{array}$ & 1.95 & 140 & .876 & .074 \\
\hline
\end{tabular}

Table 12. Summary of Sample T-test for the Post-test scores.

\begin{tabular}{|c|c|c|c|c|c|c|c|c|c|}
\hline \multicolumn{10}{|c|}{ Paired Samples Test } \\
\hline & & \multicolumn{5}{|c|}{ Paired Differences } & \multirow[b]{3}{*}{$\mathrm{t}$} & \multirow[b]{3}{*}{$\mathrm{df}$} & \multirow{3}{*}{$\begin{array}{c}\text { Sig. } \\
\text { (2-tailed) }\end{array}$} \\
\hline & & \multirow[b]{2}{*}{ Mean } & \multirow[b]{2}{*}{ Std. Deviation } & \multirow{2}{*}{$\begin{array}{l}\text { Std. } \\
\text { Error } \\
\text { Mean }\end{array}$} & \multicolumn{2}{|c|}{$\begin{array}{l}95 \% \text { Confidence } \\
\text { Interval of the } \\
\text { Difference }\end{array}$} & & & \\
\hline & & & & & Lower & Upper & & & \\
\hline Pair 1 & $\begin{array}{c}\text { Multimedia Method } \\
\text { Test Score - } \\
\text { Traditional Method } \\
\text { Test Score }\end{array}$ & 1.614 & 1.063 & .090 & 1.437 & 1.792 & 17.962 & 139 & .000 \\
\hline
\end{tabular}


HO1: No significant difference exists between the mean scores of the experimental and control groups.

The result from table 12 showed that the paired sample test found the difference to be significant, $\mathrm{t}(139)=$ 17.962, $\mathrm{p}<0.001$. This implies that there is a significant difference between the mean scores of the students taught with the multimedia method of teaching and the students taught with the traditional chalk and talk method of teaching which rejects the null hypothesis that there is no significant difference between the mean scores of both methods.

\section{DISCUSSION}

In relation to the findings gathered on the study of the assessment of multimedia technology in the teaching of Mathematics in secondary schools in Abuja, there was a clear difference between the performances of the students that were taught with multimedia teaching method (experimental group) and the traditional chalk and talk method (control group). The results from the descriptive statistics and the paired sample test showed that the students taught with the multimedia method had higher mean scores than those taught with the traditional chalk and talk method. This implies that the multimedia technology method boost the teaching of mathematics among students than the traditional chalk and talk method. In addition, the results shown from the frequency and percentage analysis of the questionnaire questions, clearly explained with the responses and the pie charts illustrations that the students mostly preferred the multimedia method of teaching which helped to boost their interest in Mathematics. The multimedia method of teaching increased the participation and motivation of the students during classes as the students were clearly captivated while teaching was ongoing and as such, their performance in the selected topic during the mathematics class was boosted. From the results, one can state clearly that with the presence of multimedia technological materials for teaching, the learning capacity and interest of the student was greatly improved upon and the performance of the secondary students in Mathematics was highly significant.

Many studies have pointed out the positive effect multimedia technology method has on the attitudes of students, their motivation and their attention during classes. Some of the related work reviewed in this study has shown that multimedia technology greatly influenced the students' learning process in mathematics. In the study carried out by [9] using ANCOVA to analyze the post-test. The result showed that using multimedia technology method of teaching gave a positive influence on the academic performance of the students. Similarly, in the study done by [10] to examine the issues related to new methods of integrating technology into Mathematics education using multimedia technology, the result showed that multimedia based teaching and learning process greatly influenced the performance of the students positively in the Calculus and Numerical module method.

\section{CONCLUSION}

The results obtained from this study have shown that multimedia technology method has helped in assessing the performance of the students by drawing their attention to the subject "Mathematics". The multimedia technology method greatly improved the students' performance positively and also made the learning process more enjoyable, more attractive and provided for a better and clearer comprehension of the topic that was taught in Mathematics to the students. The pie chart illustrations with the frequencies and percentages related to the responses from the questionnaires clearly showed that the students preferred the multimedia technology method of teaching to the traditional chalk and talk method. The result of the descriptive statistics showed there a higher mean score for the multimedia method than the tradition method. Also, the result from paired sample t-test analysis showed that there was a significant difference in the mean score of both teaching methods. In conclusion therefore, the multimedia technology method of teaching has impacted positively on the improvement and interest of secondary school students in Mathematics.

\section{REFERENCES}

[1] Richey, R. Reflections on the 2008 AECT Definitions of the Field, Tech trends, 2008, 52 (1): 24-25.

[2] Prensky, M. The Role of Technology in Teaching and the Classroom. Educational Technology, 2008, 48 (6): 1-3.

[3] Agarwal, A. and Malik, S. Use of Multimedia as a New Educational Technology Tool - A Study. International Journal of Information and Education Technology (IJIET), 2012, 2 (5): 468-471.

[4] Neo, M, and Neo, T. Engaging Students in Multimediamediated Constructivist Learning Student's Perceptions. Journal of Educational Technology and Society, 2009, 12 (2): 254-256.

[5] Sawsan, N., Izzat, A., Mohammed A., and Fatima, S. Studying the Impact of Using Multimedia Interactive Programs at Children Ability to Learn Basic Math Skills. Acta Didactica Napocensia, 2012, 5 (2): 17-32.

[6] Odogwu, H. A Comprehensive Guide for Teaching Mathematics in Secondary Schools, 2014.

[7] Zhang, J. Multimedia Technology in Mathematics Teaching Optimization. In: Wu Y. (eds). Advanced Teaching- Proceedings of the $20093^{\text {rd }}$ international Conference on Teaching and Computational Science (WTCS). Advances in Intelligent and Soft Computing. Springer Berlin, Heidelberg, 2012, 117: 357-363.

[8] Adebule, S. Gender Differences on a Locally Standardized Anxiety Rating Scale in Mathematics for Nigerian Secondary Schools. Journal of Counseling and Applied Psychology, 2004, 1: 22-29.

[9] Oyebola, A. Effect of the Use of Multimedia on Students' Performance in Secondary School Mathematics. Global Media Journal, 2018, 16 (30): 1-8.

[10] Haftamu, M. Abdul Hadi, B. and Raza, H. Impact of Multimedia in Teaching Mathematics. International Journal of mathematics Trends and Technology, 2016, 39 (1): 80-83.

[11] Joel, S., Betty, M. and Mussa, M. Factors Influencing Teachers' Use of Multimedia Enhanced Content in Secondary Schools in Tanzania. International Review of 
Research in Open and Distributed Learning, 2016, 17 (2): 65-84.

[12] Mohanaad, T., AmirAlfalahi, H. and Mohammed, A. Three Dimensional (3d) Models to Educational Multimedia Approach for simulating Parts of Shock Tunnel. Australian Journal of Basic and Applied Sciences (AENSI), 2014, 8 (9): 107-114.

[13] Ebem, D. Multimedia Based Pedagogy on mathematics in Senior Secondary Schools The case Study of Enugu State-Nigeria. African Journal of Computing and ICT, 2012, 5 (2): 31-34.

[14] Amina, S., Muhammad, I., Qaisara, P. and Malik, G. Effectiveness of Information and Communication Technology (ICT) in Teaching Mathematics at Secondary Level. International Journal of Academic Research (IJAR), 2011, 3(5): 67-72.

[15] Nwaocha, O. Enhancing Students Interest in mathematics Via Multimedia Presentation. African Journal of Mathematics and Computer Science Research, 2010, 3 (7): 107-113.

[16] Kamat, V. and Shinde, J. Enrichment of the Learning Experience of Rural Children through Interactive Media. The $6^{\text {th }}$ Pan - Commonwealth Forum on Open Learning, 2009: 1-9.

\section{Authors' Profiles}

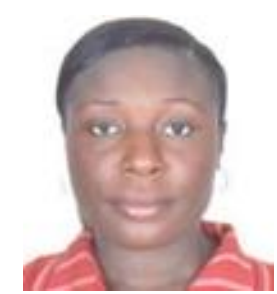

Blessing Dominic-Ugwu had a degree in Mathematics and Computer Science from the Federal University of Technology, Minna, Niger State. She had her Master's degree in Computer Science from the Federal University of Technology, Minna, Niger State. She is currently undergoing her $\mathrm{PhD}$ programme in Computer Science at the Nigerian Defence Academy, Kaduna State.

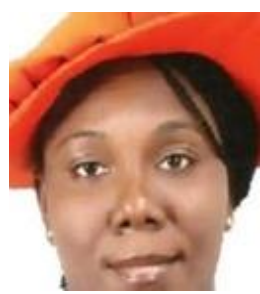

Professor Francisca N. Ogwueleka is a Professor at the Nigerian Defence Academy (NDA), Kaduna, Kaduna State. She is the dean of the Faculty of Military Science and Interdisciplinary studies (FMIS), Kaduna, Kaduna State. She had her $\mathrm{PhD}$ in Computer Science at the Nnamdi Azikiwe University, Awka in 2008. She is a member of the Computer Professionals Registration Council of Nigeria (CPN), Nigerian Computer Society (NCS), Association for Computing Machinery (ACM) and the International Association of Engineers (IAENG). She has had more than 10 years' experience in teaching and postgraduation. In research, her interest is in Big Data and Cloud Security, Data/ Information Transfer Security and Network Security, Artificial Intelligence and Expert System, Data Mining and Cyber Security Applications.

How to cite this paper: Blessing Dominic-Ugwu, Ogwueleka Francisca Nonyelum, "The Assessment of Multimedia Technology in the Teaching of Mathematics in Secondary Schools in Abuja-Nigeria", International Journal of Modern Education and Computer Science(IJMECS), Vol.11, No.6, pp. 8-18, 2019.DOI: 10.5815/ijmecs.2019.06.02 